\title{
Primary description of pythiosis in autochthonous canine from the city of Mossoró, Rio Grande do Norte, Brazil
}

Descrição primária da pitiose em canino autóctone da cidade de Mossoró, Rio Grande do Norte, Brasil

\section{Luã Barbalho de Macêdo ${ }^{1}$, Ilanna Vanessa Pristo de Medeiros Oliveira ${ }^{1}$, Muriel Magda Lustosa Pimentel ${ }^{2}$, Paulo Fernando Cisneiros da Costa Reis ${ }^{3}$, Michelly Fernandes de Macedo ${ }^{4}$, Kilder Dantas Filgueira ${ }^{3 *}$}

Abstract: Pythiosis is a granulomatous infectious disease caused by the oomycete Pythium insidiosum. In Brazil, there are a considerable number of studies on that disease in dogs mainly from the state of Rio Grande do Sul. Given the unfamiliarity of the affectation in dogs from other locations, such as the Northeast, its description in native animals from federal units of this latter region becomes essential. In this sense, this study aimed to register the first case of canine pythiosis found in the city of Mossoró, Rio Grande do Norte (RN), Brazil. A two-year-old mixed breed female dog was referred to the Veterinary Hospital of the Rural Federal University of the Semi-Arid (Mossoró, RN, Brazil). Physical examination showed swelling in the anal mucocutaneous junction. During rectal palpation, lumen stenosis was detected. Laboratory screening tests were requested, but due to nonspecific results, performing incisional biopsy of the anal lesion was decided. Fragments were sent for histopathological analysis, being used special histochemical staining. Accordingly, a case of pythiosis was found. Pharmacotherapy was applied with itraconazole and terbinafine hydrochloride prescription. After three months and twelve days of treatment, complete remission of the lesions occurred. One should consider pythiosis in native dogs from the city of Mossoró, RN. Adoption of diagnosis appropriate methods is essential for early disease identification, with a positive impact on therapeutic decisions. 
Key words: Pythium insidiosum, Brazil's Northeast, diagnosis, Canis familiaris.

Resumo: A pitiose é uma doença granulomatosa decorrente da infecção pelo oomiceto Pythium insidiosum. No Brasil, há um considerável volume de estudos dessa enfermidade em cães oriundos principalmente do estado do Rio Grande do Sul. Em virtude do desconhecimento da afecção em caninos de outras localidades, como o Nordeste, torna-se fundamental o registro em animais nativos das unidades federativas de tal região. Nesse sentido, objetivou-se descrever o primeiro caso diagnosticado de pitiose em canino procedente da cidade de Mossoró, estado do Rio Grande do Norte (RN), Brasil. Uma cadela, dois anos, sem raça definida, foi encaminhada para o Hospital Veterinário da Universidade Federal Rural do Semi-Árido (localizado na cidade de Mossoró, RN, Brasil). Ao exame físico, constatou-se tumefação na junção mucocutânea anal. Durante a palpação retal detectou-se estenose do lúmen. Foram solicitados exames complementares de triagem, mas devido à inespecificidade dos mesmos, optou-se em executar biopsia incisional da lesão anal. Os fragmentos obtidos foram enviados para análise histopatológica, com o uso de coloração especial histoquímica. Tal prova laboratorial conduziu ao diagnóstico de pitiose. Foi realizada terapia medicamentosa, com a prescrição de itraconazol e cloridrato de terbinafina. Após três meses e doze dias de tratamento, ocorreu completa remissão lesional. Deve-se considerar a pitiose como uma possibilidade diagnóstica em cães autóctones do município de Mossoró, RN. A adoção de exames complementares específicos é essencial para a identificação precoce da doença, com reflexo positivo na conduta terapêutica e evolução clínica do paciente.

Palavras chave: Pythium insidiosum, nordeste brasileiro, diagnóstico, Canis familiaris. 
1 Self-employed Veterinarian, Natal, Rio Grande do Norte, Brazil. E-mail: luanb_macedo@hotmail.com

${ }^{2}$ Graduate Program in Animal Sciences, Rural Federal University of the Semi-Arid, Mossoró, Rio Grande do Norte, Brazil. E-mail: murielpimentel@ yahoo.com.br

${ }^{3}$ Veterinary Hospital, Rural Federal University of the Semi-Arid, Mossoró, Rio Grande do Norte, Brazil. E-mail: kilder@ufersa.edu.br (*corresponding author).

${ }^{4}$ Department of Animal Sciences, Rural Federal University of the Semi-Arid, Mossoró, Rio Grande do Norte, Brazil. E-mail: michelly@ufersa.edu.br

*corresponding author - kilder@ufersa.edu.br

Submetido em 12.10.2014;Aceito em 15. 12. 2014

Introduction

Pythiosis agent, Pythium insidiosum, is a zoosporic microorganism, kingdom Straminipila, class Oomycetes, order Pythiales, family Pythiaceae, which inhabits the soil and aquatic environments (TROST et al., 2009). Corresponds to a eukaryotic microorganism similar to fungi in some morphological and growth characteristics, however, phylogenetically distant from members of the kingdom Fungi (GALIZA et al., 2014). Currently, $P$. insidiosum is more closely related to the algae
(GROOTERS \& FOIL, 2012). Environmental conditions are crucial for the organism development in its ecosystem. For its cycle maintenance, P. insidiosum requires water accumulation and high temperature (NONNEMACHER et al., 2009; TROST et al., 2009; MARTINS, 2011). Among the affected species, horses, ruminants, dogs, cats, some wild animals, and humans can be mentioned. However, there is neither intra nor interspecific transmission between hosts (GROOTERS \& FOIL, 2012). The horses are more commonly affected, 
followed by the canines, whose gastrointestinal manifestation is more prevalent in relation to dermatological (SANTURIO et al., 2006; GALIZA et al., 2014).

With regard to the distribution of canine pythiosis in Brazil, there is a considerable volume of studies, mainly in the state of Rio Grande do Sul (Rech \& Graça, 2004; Trost et al., 2009; Hunning et al., 2010; Martins, 2011; Maroneze et al., 2012) and also in Paraná (Froes et al., 2009), São Paulo (Torres-Neto et al., 2010), Minas Gerais (Cavalcanti-Júnior et al., 2007) and Mato Grosso (STRAGLIOTTO et al., 2011). In the Northeast, there is minimal knowledge of pythiosis in dogs, with only a single description in the state of Paraíba (TÔRRES et al., 2013).

In addition to the published cases, informal reports from veterinarians indicate the presence of the disease in several states (LEAL et al., 2001). Due to the shortage of data associated with pythiosis in dogs from Brazil's Northeast, it becomes essential the record of such a disease in native animals from the federal units of that region. In this sense, the present study aimed to describe the first pythiosis case diagnosed in an autochthonous canine in the city of Mossoró, state of Rio Grande do Norte, Brazil, and to report the epidemiological, clinical, laboratorial, therapeutic and prognostic aspects of canines stricken by pythiosis.

\section{Materials and Methods}

A two year old mixed breed female canine, weighing $15.2 \mathrm{~kg}$ was referred to the Veterinary Hospital of the Rural Federal University of the Semi-Arid (Mossoró, RN, Brazil). The patient had history of weight loss, hematochezia and dyschezia with evolution longer than twenty days. Feces exuded putrid odor and reduced consistency. The anal region presented swelling and injuries suffering constant 
licks and bites at the site. However, good general conditions with normorexia, normodipsia and normuria were also present. No episodes of emesis occurred. The dog was wandering, but, a year before, had been confined to home environment, having contact with two intraspecific individuals (which showed no apparent changes). Its food consisted of commercial feed and its water was not potable. The deworming protocol was updated. The dog was nulliparous and not spayed.

The patient underwent physical examination. The option was to request some additional tests which corresponded to complete blood count (CBC) with platelet count, serum chemistry (creatinine, alanine aminotransferase, alkaline phosphatase, total proteins and fractions, and glucose addition), abdominal ultrasonography, leishmaniasis serology (since the geographical area was endemic for this disease), and anal cytology of the mucocutaneous site by non aspriration puncture technique with fine needle. Incisional biopsy of the lesion in the anal mucocutaneous junction was recommended. Initially, the animal underwent premedication with acepromazine $\quad\left(0,1 \mathrm{mg} \cdot \mathrm{kg}^{-1}\right) \quad$ and diazepam $\quad\left(0,5 \mathrm{mg} \cdot \mathrm{kg}^{-1}\right), \quad$ both intramuscular. Induction was performed with propofol $\left(4,0 \mathrm{mg} \cdot \mathrm{kg}^{-1}\right.$, intravenous) and maintained with isoflurane in $100 \%$ oxygen. The incision performed was wedge-shaped, incorporating portions of skin and mucosa. The fragments obtained were fixed in $10 \%$ formalin and sent to a veterinary laboratory specialized in dermatohistopathology.

Pharmacotherapy was adopted, with itraconazole and terbinafine hydrochloride prescription (both at a dose of $5 \mathrm{mg} \cdot \mathrm{kg}^{-1}$, orally, every 24 hours, until further recommendation). Aiming to minimize the drug side effects, it was recommended 
administration of maropitant During rectal inspection and palpation, hydrochloride (2 mg. $\mathrm{kg}^{-1}$ orally, every it was detected stenosis around the 24 hours, for five days) and silymarin lumen, due to diffuse thickening of the (20 mg. $\mathrm{kg}^{-1}$ orally every 24 hours until organ, with the presence of multiple and new guidance). For hydration, supply of sparse tumors and nodules in the mineral water was recommended. mucosa tunic (Figure 1b).

Administrations of itraconazole, terbinafine hydrochloride and silymarin were kept, according to previous instructions.

\section{Results and Discussion}

There were normal vital parameters. However, there was an intense swelling throughout the whole circumference of the anal mucocutaneous junction, with firm consistency, erythematous and ulcerated surface, and hemorrhagic exudation (Figure 1a). 




Figure 1. Swelling and soreness in anal mucocutaneous junction

(a) and rectal mucosa thickening (b).

The same were consistent with

P. insidiosum. Staining: GMS and PAS, respectively.There were also bleeding and pain at manipulation. A palpable mass was noticed in the hypogastric abdominal area. The dog also displayed lean nutritional status, normal colored mucous membranes and no change of superficial lymph nodes. Semiology of other anatomical regions indicated no abnormalities. Hematology showed eosinophilia and monocytosis. The only significant biochemical change corresponded to hyperglobulinaemia. Imaging indicated a hypoechoic neovascularized mass, with irregular contour, amorphous and disorganized architecture. The same was found adjacent to the bladder, with projection to the pelvic cavity, suggesting iliosacral linfocenter lymphadenopathy. Serologic testing proved nonreactive. Cytological evaluation showed a marked inflammatory infiltrate, mainly composed of eosinophils and neutrophils.

Due to nonspecificity of the laboratory results, was justified by incisional biopsy of the lesion in the anal mucocutaneous junction. 
Microscopically, the epidermis showed regular hyperplasia, compact orthokeratosis and ulceration area. The whole dermis (and also the subcutaneous tissue) exhibited multinodular inflammatory reaction coalescing into severe eosinophil infiltration, besides histiocytes and neutrophils.

There were some pyogranuloma formations. No signs of neoplastic transformation, mites or foreign bodies were detected. In view of these findings, use of histochemical special stains became necessary, being Grocott Methenamine Silver Stain (GMS) and Periodic Acid-Schiff (PAS) techniques applied.
Both methods displayed positive results for the presence of a clear, thick hyphae, of varied sizes, irregularly branched and septate (Figure $2 \mathrm{a}$ and $\mathrm{b}$ ), disposed among inflammatory cells and necrotic areas.

Morphological profile was consistent with pyogranulomatous dermatitis with intense eosinophilic infiltration.

Dyeing and morphometric characteristics of the hyphae were consistent with $P$. insidiosum. Accordingly, a pythiosis framework was observed in the anal mucocutaneous junction. 

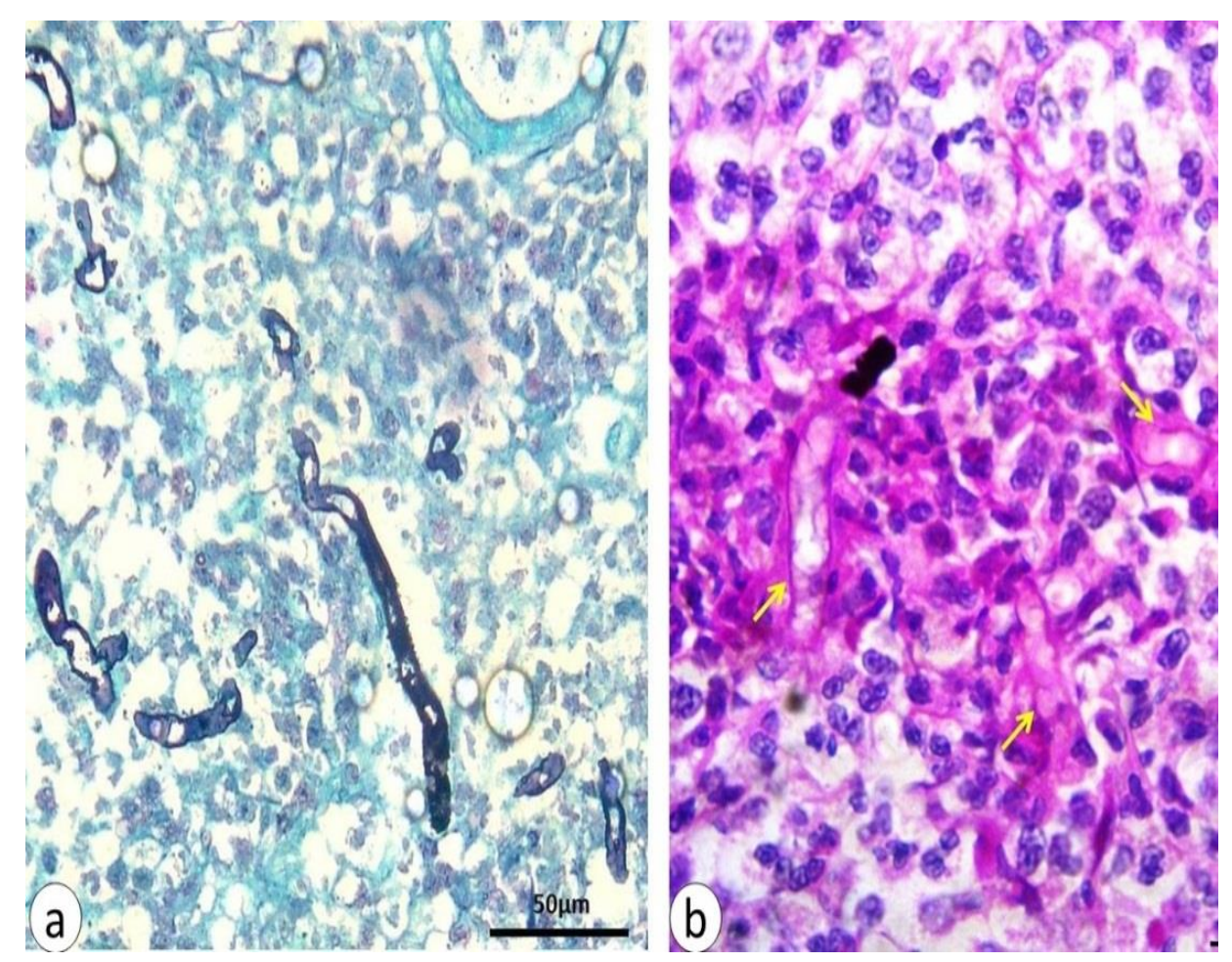

Figure 2. Histopathological photomicrograph elucidating hyphae presence of multiple sizes and irregularly chambered (a) clear and thick, among inflammatory cells (b).

Thirty days after the beginning of the treatment the animal returned.

There were no reports of adverse reactions to use of antifungal, such as loss of appetite, anorexia, lethargy, jaundice, vomiting, diarrhea and rashes. There were no hematochezia or dyschezia evidences. Feces had completely normal consistency and characteristic odor. There was a 3.7 kilogram weight increase. Vital parameters remained unchanged. Absence of swelling in the anal region was detected, but still presenting erythematous and ulcerated surface (Figure 3a). There was no pain or bleeding on palpation of the rectum, being predominant thickening detected only on its dorsal face. Hematological, biochemical and ultrasound monitoring were carried out, with no abnormality indication. After three months and 
twelve days from initiating therapy, the patient's follow-up was performed once more. Clinical and laboratory profiles remained satisfactory (similarly to previous assessment). In addition, there was complete remission of the gross changes in the anal mucocutaneous junction (Figure 3b) and rectal surface. At that moment, the bitch exhibited $21 \mathrm{~kg}$ body weight, conferring normal nutritional status. The treatment completion was authorized, being clinic release accorded. Mineral water maintenance and access prevention to wetlands were recommended. Currently, the animal is found in proper sanitary condition, with no clinical disorders related to pythiosis.

In canine species, infections caused by $P$. insidiosum are usually associated with continuity solution immersion (whether skin and / or mucous gastroenteric) in contaminated water at high temperatures (MARTINS, 2011). The zone between $28^{\circ} \mathrm{C}$ and $40^{\circ} \mathrm{C}$ favors adequate oomycete development (LEAL et al., 2001). Thus, the reported bitch was subjected to risk factors that led to the disease acquisition, such as origin region and previous life style. The female was continuously exposed to tropical climate, with temperatures up to $36^{\circ} \mathrm{C}$ (as a native dog from the Northeastern Brazil, more specifically the city of Mossoró, RN). Moreover, before getting responsible ownership, it was homeless, being a wandering individual. Therefore, possible external and internal traumas occurred daily, arising from disputes with other dogs (or even evil human actions) and also due to ingestion of food waste (such as bones) or foreign bodies. In parallel, there might have been access to many different environments, including those with water accumulation, which housed the $P$. insidiosum zoospores (and consequent direct contact through different routes, such as transcutaneous 
and digestive). Epidemiological data related to body size and patient's age also corresponded to predisposing factors for the condition, according to literature (HUNNING et al., 2010; FERNANDES et al., 2012).
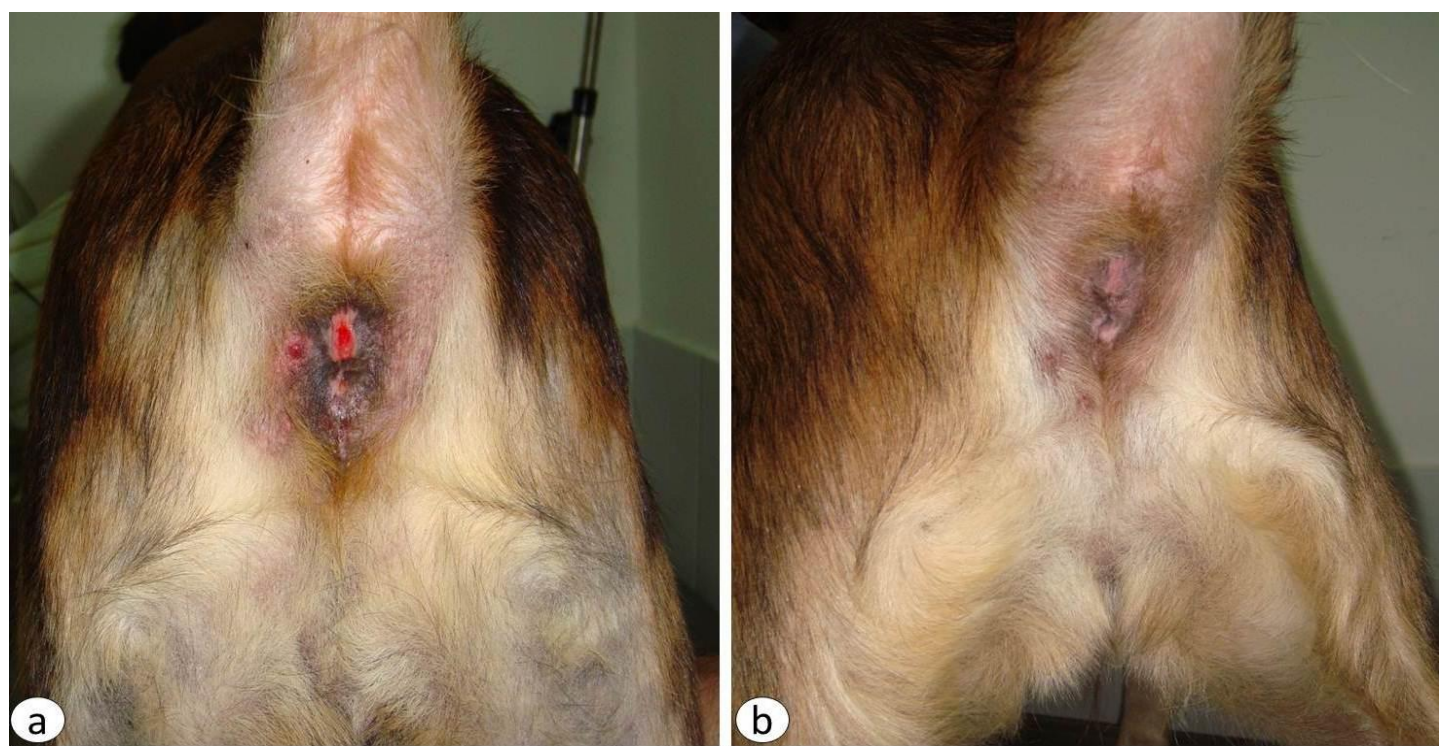

Figure 3. Pythiosis partial (a) and complete remission (b) in anal mucocutaneous junction.

Studies related to canine pythiosis are mainly concentrated in the South and Southeast of Brazil (Rech \& Graça, 2004; Cavalcanti-Júnior et al., 2007; Froes et al., 2009; Trost et al., 2009; Torres-Neto et al., 2010; Hummel et al., 2011; Martins, 2011; Maroneze et al., 2012). In other areas such as the Northeast, several scientific descriptions of the disease have been observed for horses (Leal et al., 2001), donkeys
(Assis et al., 2008), cattle (Assis et al., 2008; Galiza et al., 2014) and sheep (Carrera et al., 2013), thus demonstrating the epidemiology for the disease in the domestic animals of such a region. However, the same is not observed for canines. According to a bibliographical survey, as for the Northeast, only a recent report on pythiosis in dogs was made in the city of Patos, Paraíba (TÔRRES et al., 
2013). The notification deficit for dogs does not mean that $P$. insidiosum is unusual in the Northeastern federal units. Despite the semiarid climate (reduced rainfall and decrease in volume of natural water reservoirs during the annual dry season), high ambient temperature is favorable for the disease establishment. Actually, what must occur is underdiagnosis either by absence of clinical suspicion or lack of directing the tissue samples to specialized veterinary histopathology laboratories. This assumption came to be reinforced by other authors, who stated that few manuscripts on pythiosis are recognized annually (regardless of infected species) due to disregard for the disease occurrence, particularly in developing countries (GAASTRA et al., 2010). Based on the assumptions outlined above, one is encouraged to assert that this case was equivalent to the first record of canine pythiosis in the city of Mossoró, RN, and one of the only cases ever mentioned, for this species, throughout Northeastern Brazil. Even though no histopathological or microbiological exams of the rectal tissue or intrapelvic lymph node were conducted, the changes in those structures were probably derived from $P$. insidiosum infection. Accordingly, the work on exposure followed the mixed form of the disease (i.e. skin / mucocutaneous and gastrointestinal manifestations, simultaneously). However, this concomitant performance is hardly found in the same dog (MILLER et al., 2013). Intestinal dysfunction was possibly a result of water consumption polluted by $P$. insidiosum (where the tissue infiltration was favored by local previous injury). Yet, there was still the possibility of rectal disorder be secondary to mucocutaneous anal injury. Although rarely, tegumentary form of canine pythiosis can induce hyphae spread by angio invasiveness 
mechanism, that is, vascular wall invasion (MARTINS, 2011).

Skin and gastroenteric symptoms displayed by the patient showed similarity to some studies (Nonnemacher et al., 2009; Trost et al., 2009; Hunning et al., 2010). However, diverging from others (Froes et al., 2009; Maroneze et al., 2012), the animal in discussion presented no emesis. This fact might be explained by the lesion location, once episodes of vomiting occur only when the disease affects the initial portion of the stomach wall and the small intestine, leading to a partial or total obliteration of these organs' lumen and, therefore, hindering flow of food content. Signs of depression or lethargy are typical only in obstruction, infarction, or rupture of the digestive tract (TROST et al., 2009; HUNNING et al., 2010). Thus, the citation above could explain the maintenance of alert behavior showed by the animal at all assessment times.
Young dogs which externalize chronic condition of inappetence, weight loss, vomiting, diarrhea and palpable masses in the abdomen (and coming from rural areas and / or with access to areas with water accumulation) should have gastroenteric pythiosis as differential diagnosis (TROST et al., 2009; HUNNING et al., 2010). Despite the habit of frequently licking and biting the affected mucocutaneous area (selfmutilation condition due to pain and / or itching), the dog showed no apparent disorders in oral cavity or adjacent tissues. This situation could be justified since there is no evidence that the transmission medium by implantation happens, once the biflagellate zoospores (infective form of $P$. insidiosum) do not occur in granulomatous lesions (RECH \& GRAÇA, 2004).

Clinicopathologic observations indicate that changes are slowly triggered after infection $(\mathrm{RECH} \&$ GRAÇA, 2004). In cutaneous cases, the 
lesion progress takes approximately six months and, when there is gastroenteric disorder, progression reaches three months (MARTINS, 2011). According to such information, one could establish that the bitch described did not present an advanced stage of disease (despite the significant abnormalities found), which contributed to satisfactory clinical outcome. In pythiosis, the impairment of abdominal and pelvic lymph nodes is characterized as a single consistent mass with increased volume. That might be due to inflammatory and hyperplastic reaction process (usually granulomatous) to $P$. insidiosum, infiltrated in adjacent organs, or to etiologic agent dissemination, through lymphatic vessels, carrying numerous hyphae into lymph nodes (LEAL et al., 2001; HUNNING et al., 2010). In the case in point, the lymphadenopathy, suggested by ultrasound image, was probably equivalent to disease reflection installed in the terminal portions of the digestive tract. Nevertheless, there may be involvement of intracavitary lymph nodes with no lesions elsewhere (TROST et al., 2009; MARTINS, 2011).

In circumstances of chronic tissue damage, severe eosinophil chemotaxis occurs in the affected region, causing temporary circulatory eosinopenia, but, with continued lesional stimulus, there is a compensatory systemic eosinophilia produced by the bone marrow (BUSH, 2004). Due to the particular monocyte ability to destroy intracellular pathogens and organisms that cause granulomatous injuries, monocytosis is an inevitable feature of chronic infectious diseases (BUSH, 2004). Therefore, $P$. insidiosum antigen persistence, inside tissues of the affected bitch, justified such hematological findings. Hyperglobulinaemia finding was attributed to chronic inflammation associated with such an infectious 
agent. This change in dogs carrying pythiosis has also been confirmed by other authors (LEBLANC et al., 2008; HUMMEL et al., 2011; FERNANDES et al., 2012). When eosinophil is the predominant cell type in cytological samples (with percentage greater than $10-20 \%$ ), the inflammatory process is classified as eosinophilic (RASKIN \& MEYER, 2011; GRANDI et al., 2014). During $P$. insidiosum penetration in the organs, there is exoantigen production. The latter triggers an immediate immune response by $\mathrm{T}$ lymphocyte helper 2, with the presence of eosinophils, mast cells, immunoglobulin E, and interleukins 4 and 5. High number of eosinophils (and mast cells) degranulated around the hyphae are primarily responsible for the extensive tissue damage found in pythiosis (MARTINS, 2011). For the animal in question, the above quote legitimized the eosinophil preponderance on cytology, as well as their relationship with the exuberant lesional presentation. Similarly, this cellular finding was observed in other clinical records of canine pythiosis (HUNNING et al., 2010; FERNANDES et al., 2012). However, besides pythiosis, various disorders can lead to eosinophilic local inflammation, such as fungal infections, parasitic migration, allergic diseases, complex eosinophilic granuloma, reaction to foreign bodies, mast cell tumors, and other neoplastic conditions that cause eosinofilopoese (RASKIN \& MEYER, 2011; GRANDI et al., 2014). Traditionally, canine pythiosis acknowledgment is based on histopathology and / or the agent isolation, through its cultural, morphological and reproductive features (SANTURIO et al., 2006). However, lesions are often mistaken for neoplasms and fresh material is not collected, making culture impossible (TROST et al., 2009). Accordingly, in clinical routine, histopathology ends up 
being the main diagnosis method, as observed in the present report. However, early disease identification by histopathology can get difficult (Santurio et al., 2006), especially because, in most of the situations, the diagnosis is made only post-mortem, without able time to treatment, and, when this is performed, the cure indexes are minimal (MARONEZE et al., 2012). The present case differed from the above quote once the tissue microscopic analysis allowed premature determination of the etiologic agent, which resulted in the patient's satisfactory clinical-therapeutic progression. Histopathology of the prevalent pyogranulomatous eosinophilic inflammation, typical of canine pythiosis, and demonstrated by other authors (Hunning et al., 2010), was consistent with the present work. Usually, when there is abundant eosinophil infiltration, $P$. insidiosum hyphae remain intact (MARTINS,
2011). This characteristic may have favored the microorganism impregnation by the histochemical staining employed, consequently leading to a definitive diagnosis. It is noteworthy that both GMS and PAS techniques were effective in identifying the agent, corroborating other studies (TORRES-NETO et al., 2010). But, our data diverged from certain studies (Grooters, 2003; Trost et al., 2009), which mentioned that hyphae are properly stained by GMS, unlike PAS. Changes in the cell wall etiologic agent could explain its reduced affinity for the PAS protocol, in some circumstances (TROST et al., 2009). The inflammatory reaction type seems to be involved in different clinical courses of pythiosis, observed among the several animal species studied. There was morphological evidence that the injury perpetuation is associated with eosinophilic response (MARTINS, 2011). Thus, considerable 
dermosubcutaneous eosinophil can evolve into deteriorated clinical infiltration in the examined bitch condition that leads to spontaneous possibly justified absence of selfdeath or euthanasia (TROST et al., limiting condition for the disease, with 2009). However, an antifungal persistent anatomical damage until the synergistic action has already been therapeutic effect had begun. In revealed (Hunning et al., 2010), when contrast, spontaneous healing the combination of itraconazole, predominates in cattle. This fact is terbinafine hydrochloride and attributed to granulomatous mefenoxam presented satisfactory inflammation triggered by this host, which, unlike the eosinophilic, has a greater role in fighting hyphae (MARTINS, 2011).

Regarding the reported dog, impossibility of surgical removal of the anal swelling (and other changes), led to adoption of pharmacotherapy. However, the use of systemic antifungal agents may not be effective (either to dogs or to other species affected) because $P$. insidiosum cell wall usually carries no (or little quantity) of ergosterol, which is the target substance of most antifungal drugs (FERNANDES et al., 2012; MILLER et al., 2013). Thus, dogs results in an 18 month treatment (HUMMEL et al., 2011). High dose administration of antifungal agents is also recommended (TORRES-NETO et al., 2010). For the animal in question, there was divergence regarding the number of administered drugs and long lasting therapy. A dog clinical healing has already been achieved when only itraconazole and terbinafine hydrochloride were prescribed (for three months), but in combination with six doses of immunotherapy Pitium $\mathrm{Vac}^{\circledR}$ (MARONEZE et al., 2012). Thus, for the situation in evidence, there was similarity to the authors cited above 
with regard to association of antifungal chemical substances and lasting of treatment, disagreeing only in relation to immunotherapy use. However success has been observed when these drugs were used for a shorter period (about 60 days), although in conjunction with application of surgical techniques (HUNNING et al., 2010). Itraconazole tissue levels (especially in the skin) are five times higher than blood, while terbinafine hydrochloride rapidly binds to plasma proteins, possesses rapid diffusion through the dermis and is concentrated in lipophilic stratum corneum (NOBRE et al., 2002). Therefore, in the present report, both drugs simultaneous action justified the successful therapy and, consequently, a favorable prognosis. Due to the fact that immunotherapy leads to cure through the establishment of predominant cellular immune response (Martins, 2011), its use could also have been valid. However the difficulty of access to the product precluded its adoption in the described patient's the treatment.

\section{Conclusion}

Pythiosis should be included in differentiation of certain diseases which affect autochthonous dogs from the city of Mossoró, RN, Brazil. Probably, this consideration also becomes relevant for canines from other northeastern cities in the country. Adoption of appropriate diagnosis methods is essential for the disease early identification, with a positive impact on the animal's therapeutic management and prognosis.

\section{References}

ASSIS, A.C.O.; MIRANDA-NETO, E.G.; MEDEIROS, J.M.A.; MEDEIROS, J.M.; SILVA， T.R.; NÓBREGA-NETO, P.I.; LIMA, S.M. Estudo retrospectivo dos casos de pitiose diagnosticados no hospital veterinário da Universidade Federal de Campina Grande, Patos, Paraíba. Ciência Veterinária nos Trópicos, v.11, n.1, supl.2, p.323, 2008. 
BUSH, B.M. Interpretação de resultados laboratoriais para clínicos de pequenos animais. São Paulo: Roca, 2004. 376p.

CARRERA, M.V.; PEIXOTO, R.M.; GOUVEIA, G.V.; PESSOA, C.R.M.; JESUS， F.P.K.; SANTURIO, J.M.; BOTTON, S.A.; COSTA, M.M. Pitiose em ovinos nos estados de Pernambuco e Bahia. Pesquisa Veterinária Brasileira, v.33, n.4, p.476-482, 2013. CAVALCANTI-JÚNIOR, H.H.; DEL BARRIO, M.A.M.; GIORDANO, P.P.; ELSTON, L.B.; OLIVEIRA NETO, F.A.; SANTOS, C.F. Gastrite granulomatosa em Retriever do Labrador pela infecção por Pythium insidiosum - relato de caso. In: CONGRESSO PAULISTA DE CLÍNICOS VETERINÁRIOS DE PEQUENOS ANIMAIS, 7., 2007. São Paulo. Anais... São Paulo: AnclivepaSP, 2007. p.50-52.
FERNANDES，C.P.; GIORDANI，C.; GRECCO, F.B.; V SALLIS, E.S.; R STAINKI， D.; GASPAR， L.F.; GARCEZ RIBEIRO, C.L.; NOBRE, M.O. Gastric pythiosis in a dog. Revista Iberoamericana de Micología, v.29, n.4, p.235-237, 2012.

FROES， T.R.; PAIVA， S.C.C.S.; LIMA, L.; AFONSO, D.O.; WERNER, J. Diagnóstico clínico e ultrassonográfico da pitiose canina: relato de caso. Clínica Veterinária, v.14, n.80, p.28-32, 2009.

GAASTRA, W.; LIPMAN, L.J.A.; DE COCK, A.W.A.M.; EXEL, T.K.; PEGGE, R.B.G.; SCHEURWATER, J.; VILELA, R.; MENDOZA, L. Pythium insidiosum: an overview. Veterinary Microbiology, v.146, n.1-2, p.1-16, 2010

GALIZA， G.J.; DA SILVA， T.M.; CAPRIOLI， R.A.; BARROS， C.S.; IRIGOYEN， L.F.; FIGHERA， R.A.; LOVATO, M.; KOMMERS, G.D. Ocorrência de micoses e pitiose em 
animais domésticos: 230 casos.

Pesquisa Veterinária Brasileira, v.34, n.3, p.224-232, 2014.

GRANDI, F.; BESERRA, H.E.O.; COSTA, L.D. Citopatologia veterinária diagnóstica. São Paulo: Medvet, 2014. 164p.

GROOTERS, A.M. Pythiosis, lagenidiosis, and zygomycosis in small animals. The Veterinary Clinics of North America: Small Animal Practice, v.33, n.4, p.695-720, 2003.

GROOTERS, A.M.; FOIL, C.S. Miscellaneous fungal infections. In: GREENE, C.E. Infectious diseases of the dogs and cats. 4.th. St Louis: Elsevier, 2012. cap.65, p.675-681.

HUMMEL， J.; GROOTERS， A.; DAVIDSON， G.; JENNINGS， S.; NICKLAS, J.; BIRKENHEUER A. Successful management of gastrointestinal pythiosis in a dog using itraconazole, terbinafine, and mefenoxam. Medical Mycology:
Oxford journal, v.49, n.5, p.539-542, 2011.

HUNNING, P.S.; RIGON, C.T.; PAVARINI, A.; SAMPAIO, D.S.; BEHEREGARAY, W.K.; DRIEMEIER D. Obstrução intestinal por Pythium insidiosum em um cão: relato de caso. Arquivo Brasileiro de Medicina Veterinária e Zootecnia, v.62, n.4, p.801-805, 2010.

LEAL， A.B.M.; FLORES， E.F.; SANTURIO, J.M. Pitiose. Ciência Rural, v.31, n.4, p.735-743, 2001.

LEBLANC， C.J.; ECHANDI， R.L.; MOORE， R.R.; SOUZA， C.; GROOTERS, A.M.; Hypercalcemia associated with gastric pythiosis in a dog. Veterinary Clinical Pathology, v.37, n.1, p.115-120, 2008.

MARONEZE, B.P.; BOTTON, S.A.; MOTA, M.A.; LOBO, R.R.; SOARES, M.P.; VALENTE, J.S.S.; AZEVEDO, M.I.; RIBEIRO, T.C.; SALLIS, E.S.V.; SILVEIRA, D.H.; STOLL, F.; SANTURIO, J.M.; PEREIRA, D.I.B. 
Terapia combinada no tratamento da pitiose gastrointestinal em um canino.

Acta Scientiae Veterinariae, v.40, n.1, supl.1, p.36, 2012.

MARTINS, T.B. Morfologia comparada da pitiose em cavalos, cães e bovinos. Santa Maria, 2011. 105p. Dissertação (Mestrado em Medicina Veterinária) - Universidade Federal de Santa Maria, 2011.

MILLER， W.H.; GRIFFIN， C.E.; CAMPBELL, K.L. Muller \& Kirk's Small animal dermatology. 7.th. St. Louis: Elsevier, 2013. 938p.

NOBRE, M.O.; NASCENTE, P.S.; MEIRELES, M.C.; FERREIRO, L. Drogas antifúngicas para pequenos e grandes animais. Ciência Rural, v.32, n.1, p.175-184, 2002.

NONNEMACHER， D.V.F.; PIZONI, C.; CORRÊA, B.F.; DE OLIVEIRA, M.P.; MOTTA, M.A.; PEREIRA, C.M.; SCHILD, A.L.; SALLIS, E.S.V.; PEREIRA, D.I.B. Pitiose cutânea e gastrointestinal em cão. In:
CONGRESSO DE INICIAÇÃO CIENTIFICA, 18., 2009. Pelotas. Anais... Pelotas: Universidade Federal de Pelotas, 2009.

RASKIN, R.E.; MEYER, D.J. Citologia clínica de cães e gatos. 2.ed. Rio de Janeiro: Elsevier, 2011. 450p.

RECH, R.R.; GRAÇA, D.L.; BARROS, C.L.S. Pitiose em um cão: relato de caso e diagnósticos diferenciais. Clínica Veterinária, v.9, n.50, p.68-72, 2004. SANTURIO, J.M.; ALVES， S.H.; PEREIRA, D.B.; ARGENTA, J. Pitiose: uma micose emergente. Acta Scientiae Veterinariae, v.34, n.1, p.114, 2006.

STRAGLIOTTO, A.; PIRES, M.A.M.; PRESSER， C.I.; GUIMARÃES， D. Enterite granulomatosa por Pythium insidiosum em cão. In: CONGRESSO BRASILEIRO DE MEDICINA VETERINÁRIA, $\quad 38 ., \quad 3011$. Florianópolis. Anais... Florianópolis: Sociedade Catarinense de Medicina Veterinária, 2011. 
TÔRRES, L.M.; DANTAS, A.K.F.P.; Dermatology, v.21, n.2, p.202-204, ARAÚJO, K.N.; SILVA， J.K.C.; 2010.

MENDES, R.S. Pitiose cutânea em um cão - relato de caso. Acta Veterinaria Brasilica, v.7, supl.1, p.195-196, 2013. TORRES-NETO, R.; BOSCO, D.M.; AMORIM， R.L.; BRANDAO, C.V.; FABRIS， V.E.; ESTANISLAU， C.; BAGAGLI, E. Cutaneous pythiosis in a dog from Brazil. Veterinary
TROST, M.E.; GABRIEL, A.L.; MASUDA, E.K.; FIGHERA, R.A.; IRIGOYEN, L.F.; KOMMERS, G.D. Aspectos clínicos, morfológicos e imunoistoquímicos da pitiose gastrintestinal canina. Pesquisa Veterinária Brasileira, v.29, n.8, p.673-679, 2009. 